\title{
TWO NEW GENERA OF SOUTH AMERICAN COCKROACHES SUPERFICIALLY RESEMBLING LOBOPTERA, WITH NOTES ON BIONOMICS (DICTYOPTERA, BLATTARIA, BLATTELLIDAE).
}

\author{
By Ashley B. Gurney* and Louis M. Roth***
}

All cockroaches initially extrude the oötheca with the keel or the micorpylar ends of the eggs facing dorsally, but some species rotate the egg case before depositing it (Roth and Willis, I954, 1958). According to McKittrick (1964), one of the important characters for separating the Plectopterinae from the Blattellinae (both are in the Blattellidae) is the position in which the oötheca is carried just before it is deposited by the female. In the Plectopterinae, the keel of the egg case remains upright until deposition; in the Blattellinae, the oötheca is rotated so the keel and micropylar ends of the eggs face laterally, behavior characteristic of the Ectobiinae and Nyctiborinae (Blattellidae) as well as of all the Blaberidae (ovoviviparous and viviparous species). The new genera here described were recognized as a result of studies stimulated by observing the lack of rotation by a species which formerly had been assumed to be one of the Blattellinae. Therefore, in addition to presenting descriptions and biological notes, this paper provides an application of the higher categories in the classification of McKittrick (1964).

On June II, I965, one of us (L.M.R.) received some living specimens of Loboptera thaxteri Hebard from Buenos Aires, Argentina. ${ }^{1}$ When we found that the females of thaxteri do not rotate the oötheca before its deposition, we investigated the taxonomic position of Loboptera Brunner. McKittrick (1964) had reported the rotation of the oötheca by Lobopterella dimidiatipes (Bolivar), ${ }^{2}$ and as a result of this and other observations she placed it in the Blattellinae. [Loboptera decipiens (Germar) also rotates its oötheca before deposition (Lefeuvre, 1959; Roth, unpublished observations).] We

\footnotetext{
*Entomology Research Division, Agr. Res. Serv., U. S Department of Agriculture, Washington, D. C.

**Pioneering Research Division, U. S. Army Natick Laboratories, Natick, Massachusetts.

Manuscript received by the editor September 21, 1966.

${ }^{1}$ The species has been cultured easily on Purina laboratory chow. However, individuals of thaxteri were heavily parasitized by the fungus Herpomyces lobopterae Thaxter.

${ }^{2}$ For many years authors referred dimidiatipes to Loboptera, and McKittrick did so. Princis (1957) based the genus Lobopterella upon it.
} 
therefore sent specimens of thaxteri to Dr. McKittrick without identifying the material, and she placed it in the Plectopterinae. She wrote, "When I looked at it, I thought 'Loboptera' and was thoroughly surprised when I checked the genitalia."

In the past years, various species seeming to belong to the Old World genus Loboptera Brunner [type species, L. decipiens (Germar $),{ }^{3}$ an Old World species] have been described from the New World. Such generic assignment of New World species has been based primarily on superficial appearance. Two South American species, in particular thaxteri Hebard and insularis R. S. Albuquerque and Gurney, have a general appearance that is so similar to decipiens that Hebard (I932) assumed thaxteri to be an introduction from the Old World. In fact, no previously described genera appear adequate for the inclusion of thaxteri and insularis. Therefore in order to assign these species in a manner consistent with current generic concepts in the Blattaria, we are describing a separate genus for each. Although the two seem congeneric in general appearance, the differences noted in the generic key following to distinguish Agmoblatta, new genus, from Isoldaia, new genus, are fundamental.

Agmoblatta, new genus

This genus closely resembles Loboptera in general external appearance; it differs as noted in the following key. Its closest relative is Isoldaia, also known from eastern South America.

Generic description: Size medium for Blattellidae. Body with sparse slender setae slightly shorter than ist antennal segment; moderately glossy. Head very broad; interocular distance a little greater than distance between antennal sockets; vertex smooth; antennae unspecialized; maxillary palpus of moderate length, apical segment narrowly triangular. Pronotum hemispherical, moderately vaulted, posterior margin straight except near simply rounded lateral angles. Tegmen a narrow, subtriangular lateral pad; wings absent. Front femur with anteroventral margin (Fig. 8) bearing a few strong spines, I or 2 of which toward knee of decreasing length, followed by about 5 piliform spines and 3 strong apical spines of increasing length; posteroventral margin with 3 or 4 spaced, strong, short spines in apical half, a slightly longer apical spine. Middle and hind femora with strong spines on both ventral margins. Middle and hind tibiae spined in 3 series on dorsal surface. Basal tarsomere of hind tarsus slightly more than one-half length of tarsus, ventral

${ }^{3}$ Hebard (1922, p. 332) indicated the type species. 

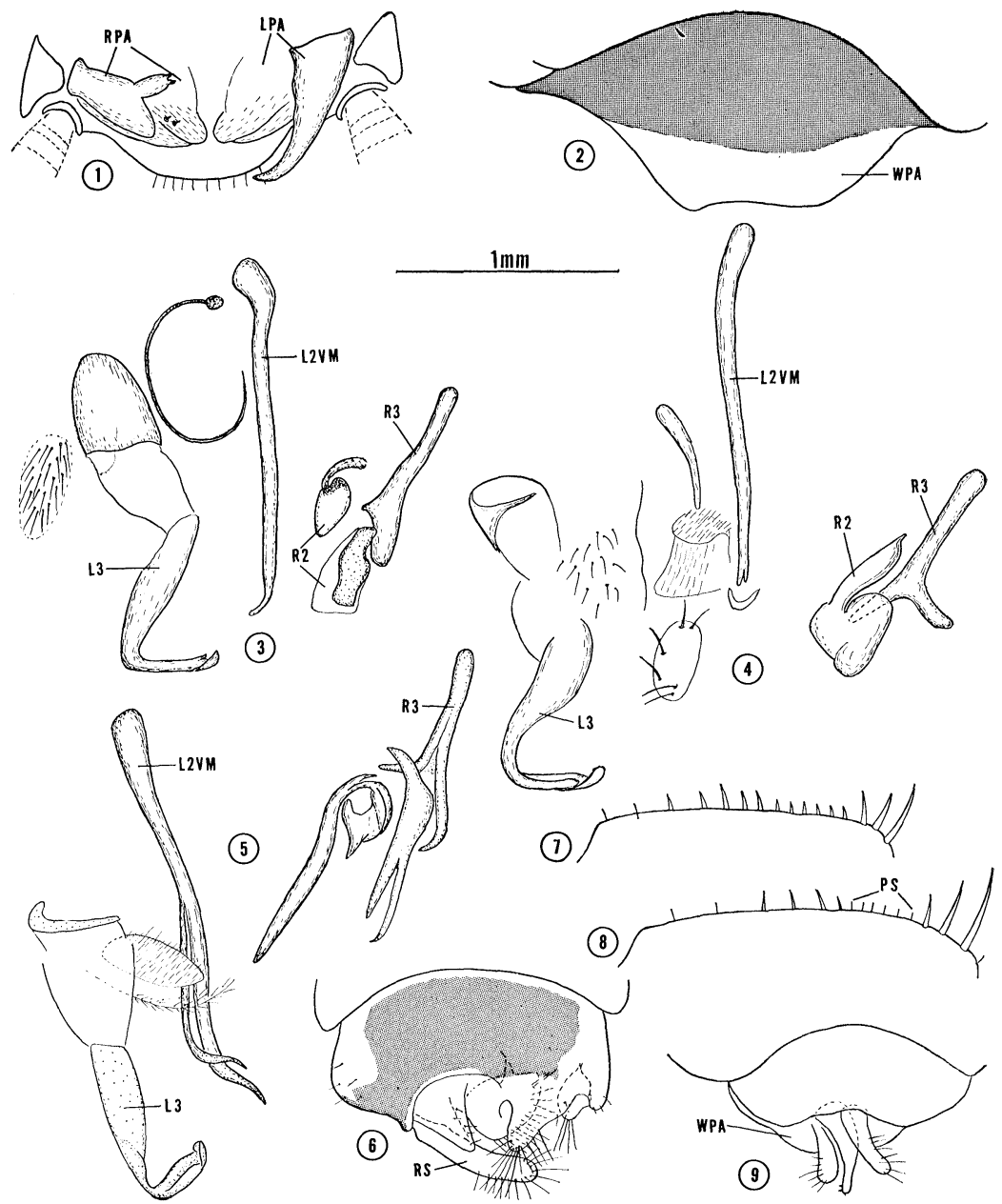

Figs. 1-9. Male genitalia of Loboptera, Lobopterella, and Agmoblatta (All figures except no. 2 drawn from $\mathrm{KOH}$ preparations)

1-3. Loboptera decipiens (Germar), male from culture at MacDonald College, originating in the Azores. 1. Ventral view of paraprocts and associated structures. 2. Ventral view of subgenital plate. 3. Dorsal view of phallomeres.

4. Loboptera maroccana Bolivar, male from Tangiers. Dorsal view of phallomeres.

5-6. Lobopterella dimidiatipes (Bolivar), male from Fiji. 5. Dorsal view of phallomeres. 6. Ventral view of subgenital plate. 
surface with double row of closely set, strong, short setae, pulvillus occupying apical Ioth of ventral surface: small pulvilli on tarsomeres I-4; claws simple, equal; arolium of moderate size.

Abdomen smooth (Figs. I5, I6); lateroposterior angles of terga simple; tergum 7 of male with a wide median depression in which a tuft of hairlike setae arises (Figs. I5, 20) ; cercus with about 9 segments. Male genitalia: Supra-anal plate broadly triangular, unspecialized; subgenital plate (Fig. 9) with specialized posterior margin, with styli; paraprocts without conspicuous specialization; phallomeres (Fig. IO) of plectopterine type, Ist sclerite of left phallomere $\left(\mathrm{LI}_{\mathrm{I}}\right)$ a conspicuous framework, median sclerite ( $\mathrm{L}_{2} \mathrm{VM}$ ) slender and elongate; 2nd sclerite of right phallomere (R2) a conspicuous hook. Female supra-anal plate triangular, simple; subgenital plate broad, posterior margin weakly cleft medially and bent dorsad (Fig. I9).

Type-species: Loboptera thaxteri Hebard.

The name Agmoblatta is derived in part from the Greek word "Agmos," meaning a break or fracture and has reference to the cleft of the female subgenital plate.

Hebard ( I932) described only the female of $A$. thaxteri and erred in suggesting that it is parthenogenetic; he based this suggestion on the fact that all his specimens were females. The male markings strongly resemble those of the female (Figs. I5, I6). The female genitalia of $A$. thaxteri and Loboptera decipiens are shown in Figs. 22 and 24. The female genitalia of Lobopterella are illustrated by McKittrick ( I964, p. I6I). Agmoblatta thaxteri has one pair of spermathecae, but each spermatheca has a double terminal bulb (Fig. 25). Loboptera decipiens also has only one pair of spermathecae (Fig. 23), but each has many amber-colored tubules or branches. Sixteen of these branches terminate in rounded colorless bulbs in which the sperm are stored. Among the species studied by McKittrick ( 1964), only members of the Blattidae and Cryptocercidae have "forked" (i.e., branched) spermathecae; none of the Blaberoi-

7. Loboptera decipiens (Germar), male from Madeira. Spines on anteroventral margin of front femur.

8-9. Agmoblatta thaxteri (Hebard). 8. Female paratype, spines on anteroventral margin of front femur. 9. Male from Natick culture originating in Buenos Aires, Argentina. Ventral view of subgenital plate.

Abbreviations: L2VM=median sclerite (second or ventromedial sclerite of left phallomere); L3 $=3 \mathrm{rd}$ sclerite of left phallomere; LPA $=$ left paraproct; $\mathrm{PS}=$ piliform spines; $\mathrm{R} 2=2 \mathrm{nd}$ sclerite of right phallomere; $\mathrm{R} 3=3 \mathrm{rd}$ sclerite of right phallomere; $\mathrm{RPA}=$ right paraproct; $\mathrm{RS}=$ right stylus; WPA $=$ weakly pigmented area of subgenital plate. 


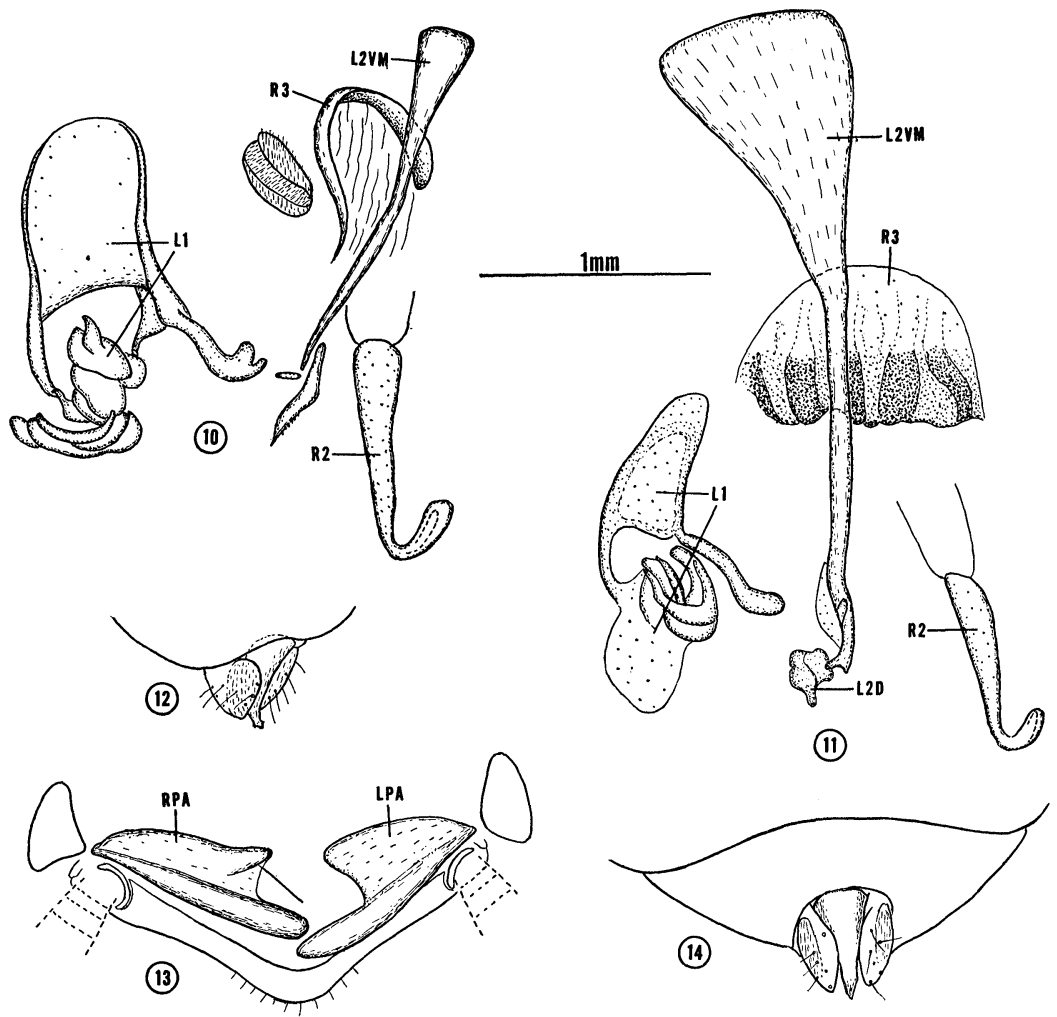

Figs. 10-14. Male genitalia of Agmoblatta and Isoldaia (All drawn from $\mathrm{KOH}$ preparations)

10. Agmoblatta thaxteri (Hebard). Male from Natick culture originating in Buenos Aires, Argentina. Dorsal view of phallomeres.

11-14. Isoldaia insularis (R. S. Albuquerque and Gurney), male holotype. 11. Dorsal view of phallomeres. 12. Ventrolateral view of apical portion of subgenital plate. 13. Ventral view of paraprocts and associated structures. 14. Ventral view of subgenital plate.

Abbreviations: $L I=1$ st sclerite of left phallomere; $L 2=$ second dorsal sclerite of left phallomere; other abbreviations as in figs. 1-9.

dea have this type of spermatheca. She believes that the branched spermatheca is a primitive condition. The many branched spermatheca in Loboptera dicipiens is unique for the Blattellidae and may represent a relic character. Lobopterella dimidiatipes has 2 pairs of spermathecae (McKittrick, 1964, p. 153).

The oötheca (Fig. I7) of $A$. thaxteri has a deep groove ventrally 
along the midline (Fig. I 8 ) made by the upturned medial cleft (Fig. I9) of the subgenital plate; the cleft serves as a mold as the oötheca is formed and extruded posteriorly. The oötheca remains upright until deposition, and its keel rests in the medial marginal indentation of the supragenital plate. The eggs require water for development, and the females usually deposit their oöthecae on the moist cotton of the water vials.

Observations were made on the courtship behavior of A gmoblatta. A newly emerged female was placed with 2 old males. Initially, the males showed only mild interest in the female, but within an hour they were actively pursuing and courting her. The males antennated and palpated the female and turned with their backs toward her, stretching and arching their abdomens and fully exposing the gland on the 7 th terga. However, the female did not respond by mounting and palpating the gland, and the males did not extend their phallomeres and attempt to grasp her genitalia. This behavior is similar to that of Blattella germanica (L.) (Roth and Willis, I952), Nauphoeta cinerea (Olivier), and other genera in which the male will not attempt to seize the female until she mounts or palpates his tergum (Roth and Barth, 1964). The male of Agmoblatta relies on antennal contact in pursuing the female; if he loses this contact, he seems to wander about haphazardly until he again makes contact, turns his back, and courts. Also, the male can discriminate between contact with a female and a male; males on touching each other did not court. This behavior is very similar to that shown by B. germanica (Roth and Willis, I952).

The female we used had not mated 2 hours after the start of observations. However, females do mate soon after emergence since a pair was seen in copula in the typical opposed position (heads facing in opposite directions) though the female was still very light in color and less than a day old. Subsequently, on days I3, 20, 25, 3I, and 39, she deposited egg cases. Thereafter she deposited no more oöthecae though she was kept until 62 days after emerging.

\section{Isoldaia, new genus}

This genus is similar superficially to Agmoblatta, from which it differs primarily in the lack of tergal specialization in the male and in the uncleft posterior margin of the female subgenital plate.

Generic description: Agrees with Agmoblatta except as follows: About IO to 12 piliform spines in apical half of anteroventral margin of front femur, in contrast to about 5 to 6 in Agmoblatta; maxillary 

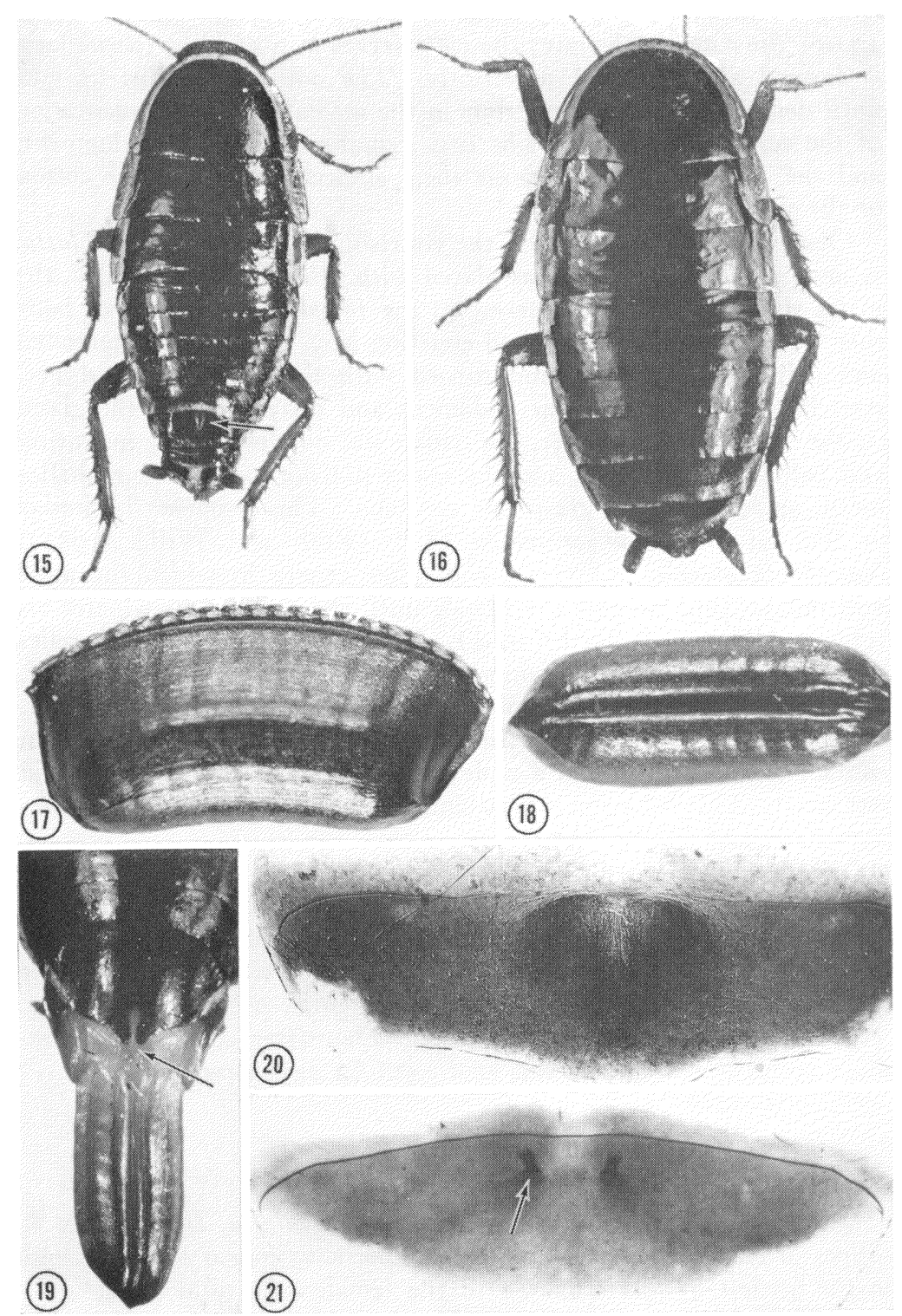

(21)

Gurney and Roth - Cockroaches 
palpus longer, exemplified by antepenultimate segment clearly more than half as long as width of interocular space (palpus shorter in Agmoblatta, antepenultimate segment decidedly less than half as long as width of interocular space); supra-anal plate of female more acutely triangular than in Agmoblatta; male abdomen without tergal specialization; subgenital plate of female with entire, uncleft posterior margin. Male genitalia and subgenital plate are illustrated in Figs. II-I4.

Type-species: Loboptera insularis R. S. Albuquerque and Gurney.

The name Isoldaia is adapted from the given name of Mrs. Isolda Rocha e Silva Albuquerque in recognition of her sustained efforts to broaden the knowledge of South American Blattaria.

A habitus figure of a female of Agmoblatta thaxteri is in Hebard (I932), and one of Isoldaia insularis is in R. S. Albuquerque and Gurney (1963). Readers are referred to page $\mathrm{I} 78$ of McKittrick (1964) for information about the subfamily assignment of the genera wherein the phallomeres of Lophoblatta Hebard, Euthlastoblatta Hebard, and Supella Shelford represent the Plectopterinae, and Pseudomops Serville and Blattella Caudell represent the Blattellinae.

The following is a key for distinguishing Loboptera and several similar genera:

I. Conspicuous hook-shaped sclerite of male genitalia occurs as part of left phallomere (Figs. 3-5, L3) ; one or both paraprocts of male armed with a hook or spines (Fig. I) ; armature of ventroanterior margin of front femur (Fig. 7) includes heavy though short spines basad of 3 terminal ones (Type A) (Old World)

- Conspicuous hook-shaped sclerite of male genitalia occurs as part of right phallomere (Figs. IO, II, R2); paraprocts of male simple, not distinctly armed (Fig. I3); armature of ventro-

\section{Explanation of Plate 14}

Figs. 15-20. Agmoblatta thaxteri (Hebard).

15. Dorsal view of male; arrow points to the tergal gland on the seventh segment $(X$ 5.2). 16. Dorsal view of female $(X 6.0)$. 17. Lateral view of oötheca $(X 17.2)$. 18. Ventral view of oötheca; note deep medial longitudinal groove $(X 17.2)$. 19. Ventral view of end of the abdomen of a female forming an oötheca; arrow points to medial cleft in subgenital plate $(X 8.8)$. 20. Seventh tergum of male showing the medial tergal gland $(X 28.7)$.

Fig. 21. Lobopterella dimidiatipes (Bolivar). Seventh tergum of male; arrow points to one of the 2 pits $(X 21.8)$. 
anterior margin of front femur includes delicate piliform spines (Fig. 8, PS) basad of 3 terminal ones (Type B) (New World)

2. Tegmina present as subtriangular lateral pads; male subgenital plate simple, without styli (Fig. 2); dorsum of male abdomen unspecialized. (Canary Islands, Azores, Europe, North Africa, western Asia; other Old World records subject to change with revised definition of genus) Loboptera Brunner

- Tegmina short, subquadrate, attingent or slightly overlapping; male subgenital plate complex, with styli (Fig. 6) ; tergum 7 of male abdomen with 2 small pores without associated setae (Fig. 2I). (Africa to Hawaii, other Pacific islands)

\section{Lobopterella Princis}

3. Dorsum of male abdomen specialized on tergum 7 (Figs. I5, $20)$; posterior margin of female subgenital plate weakly cleft (Fig. I9). (Known only from Buenos Aires, Argentina)

Agmoblatta, new genus

- Dorsum of male abdomen unspecialized; posterior margin of female subgenital plate entire. (Known only from San Sebastian Island about 60 miles east of São Paulo, Brazil)

Isoldaia, new genus

Princis (1957) stated that the male tergum is unspecialized in Lobopterella; perhaps the pores on segment 7 were hidden under the 6th tergum in his museum specimens.

Several genera of Old World Blattaria have been described to include species appearing by traditional generic characters to be related to Loboptera. Specimens of most of these genera are not available to us at present to permit us to study the characters shown by McKittrick (1964) to have special significance in higher classification. When such a study eventually becomes possible, the resulting realignment of genera may reveal which are most closely related to $\mathrm{Agmo-}$ blatta and Isoldaia and may suggest what the lines of evolutionary development have been. Brief characterizations of Loboptera and 3 European species are included in Princis ( 1965). An illustration of the paraprocts of Loboptera decipiens similar to our Fig. I, is in Bei-Bienko ( I950, p. I69, fig. 67). The description of Lobopterella is in Princis ( 1957 ).

The present investigation tests the applicability of McKittrick's higher categories and particularly her separation by genitalia and other characters of 2 groups of genera which for many years have been regarded as a single group, the Pseudomopinae. Our studies indicate that there is a basis for a fundamental distinction between 


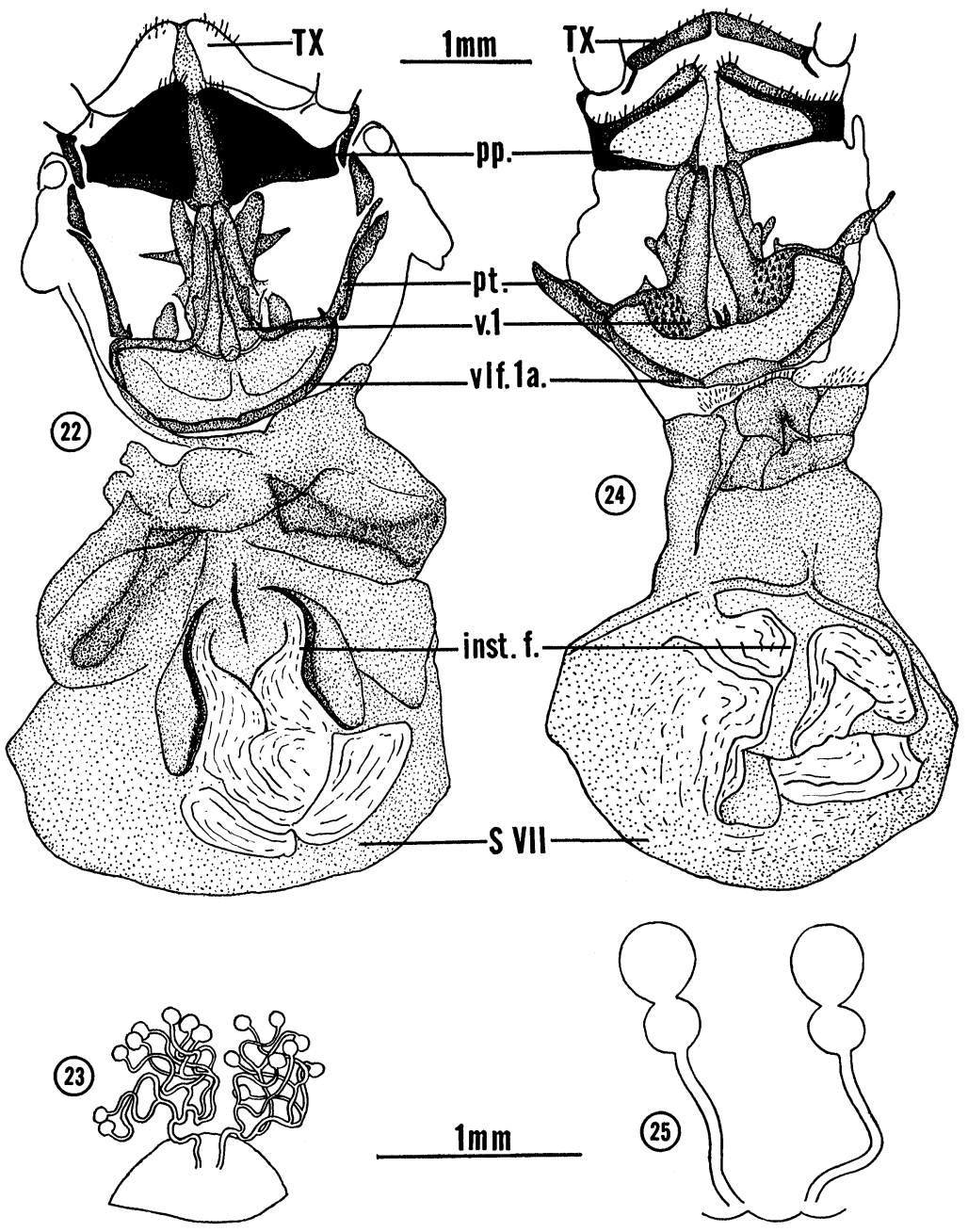

Figs. 22-23. Loboptera decipiens (Germar), female from Natick culture, originating in France. 22. Posterior view of genitalia. 23. Spermathecae. Figs. 24-25. Agmoblatta thaxteri (Hebard), female from Natick culture, originating in Buenos Aires, Argentina. 24. Posterior view of genitalia. 25. Spermathecae.

Abbreviations: inst. f. $=$ intersternal fold; pp. $=$ paraprocts; pt. $=$ paratergites; v.1 $=$ first valve; vlf. $1 \mathrm{a} .=$ first valvifer arm; S VII $=$ sternum VII; TX $=$ tergum $X$. 
her 2 groups, Plectopterinae and Blattellinae, though additional characters such as wing venation seem to require evaluation before all genera placed in Plectopterinae by McKittrick remain there permanently. Most genera of Pseudomopinae, in the sense used by Hebard for many years, were placed in the family Blattellidae by Princis ( I960) without subfamily separation. The subfamily name Pseudomopinae dates from Burr ( I9IO, p. I52), who also used the family name Pseudomopidae. [An earlier use of Pseudomopinae by Rehn (I903, p. 260) is invalid because the name was proposed as a substitute for Phyllodrominae, and this substitute is required by Article 39 of the International Code of Zoological Nomenclature to be based on the valid name of the original type-genus, i.e., Blattella Caudeil.] Karny (1908) introduced Blattellidae, and that name has priority for any higher category including both Blattella and Pseudomops. [The chronology of these group names was given by Kevan and Princis ( I96I).]

The correlation of differences in bionomics with the higher categories was also tested in our study.

We thank Dr. K. Princis for identifying "Loboptera" thaxtert, Dr. Frances A. McKittrick for examining the same, Dr. R. K. Benjamin for identifying Herpomyces lobopterae, Mr. William Hahn for taking the photographs, and Mr. Peter Graves for camera lucida outlines of Figs. 22-24. We are also grateful to Dr. Princis for reading the manuscript and offering some very helpful suggestions.

\section{REFERENCES}

Bei-Bienko, G. IA.

1950. Fauna of the U.S.S.R. Insects. Blattodea. (In Russian) Zool. Inst. Akad. Nauk., S.S.S.R., Moscow, n. s. No. 40, 343 pp., 132 figs.

BURR, M.

1910. A synopsis of the Orthoptera of Western Europe. $160 \mathrm{pp}$. London.

HeBARD, $M$.

1922. Dermaptera and Orthoptera of Hawaii. Occas. Papers B. P. Bishop Mus. 7: 1-196, 2 pls.

1932. A new species of Loboptera Brunner. Ent. News 43:60-62, 2 figs. KARNY, H.

1908. Die zoologische Reise des naturwissenschaftlichen Vereines nach Dalmatien im April 1906. B. Spezieller Teil. etc. 6. Orthoptera und Blattaeformia. Mitt. Naturw. Ver. Univ. Wien, 6: 101-113.

Kevan, D. K. McE., and K. Princis

1961. Blatta transfuga Brunnich, 1763 (Insecta, Dictyoptera); proposed suppression under the plenary powers. Z. N. (S.) 680 . Bull. Zool. Nomencl. 18 (pt. 5) : 330-331. 
Lefeuvre, J. C.

1959. Contribution à l'étude de la Biologie et de l'organogenèse des trachées alaires de Blabera craniifer Burm. 106 pp. 30 figs., 6 pls. D. E. S. Université de Rennes.

McKittrick, F. A.

1964. Evolutionary studies of cockroaches. Cornell Univ. Agric. Expt.

Princis, K. Stat. Mem. 389: 197 pp., 205 figs., 6 text-figs.

1957. Zur Kenntnis der Blattarien der Kleiner Sundainseln. Verh. Naturf. Ges. Basel 68: 132-159, 19 figs.

1960. Zur Systematik der Blattarien. Eos 36: 427-449, 15 figs.

1965. Ordnung Blattariae. Bestimmungsbucher zur Bodenfauna Europas, Lief. 3: 1-50, 56 figs.

ReHN, J. A. G.

1903. Studies in American Blattidae. Trans. Amer. Ent. Soc. 29: 259290.

Rocha, e Silva Albuquerque, Isolda, and A. B. Gurney

1963. Records and descriptions of cockroaches from southern Brazil. Studia Ent. 6: 515-536, 41 figs.

Roth, L. M. AND R. H. BarTh

1964. The control of sexual receptivity in female cockroaches. J. Ins. Physiol. 10: 965-975.

Roth, L. M. AND E. R. Willis

1952. A study of cockroach behavior. Amer. Midl. Nat. 47: 66-129.

1954. The reproduction of cockroaches. Smiths. Misc. Coll. 122: 1-49, 94 figs.

1958. An analysis of oviparity and viviparity in Blattaria. Trans. Amer. Ent. Soc. 83: 221-238, 59 figs. 

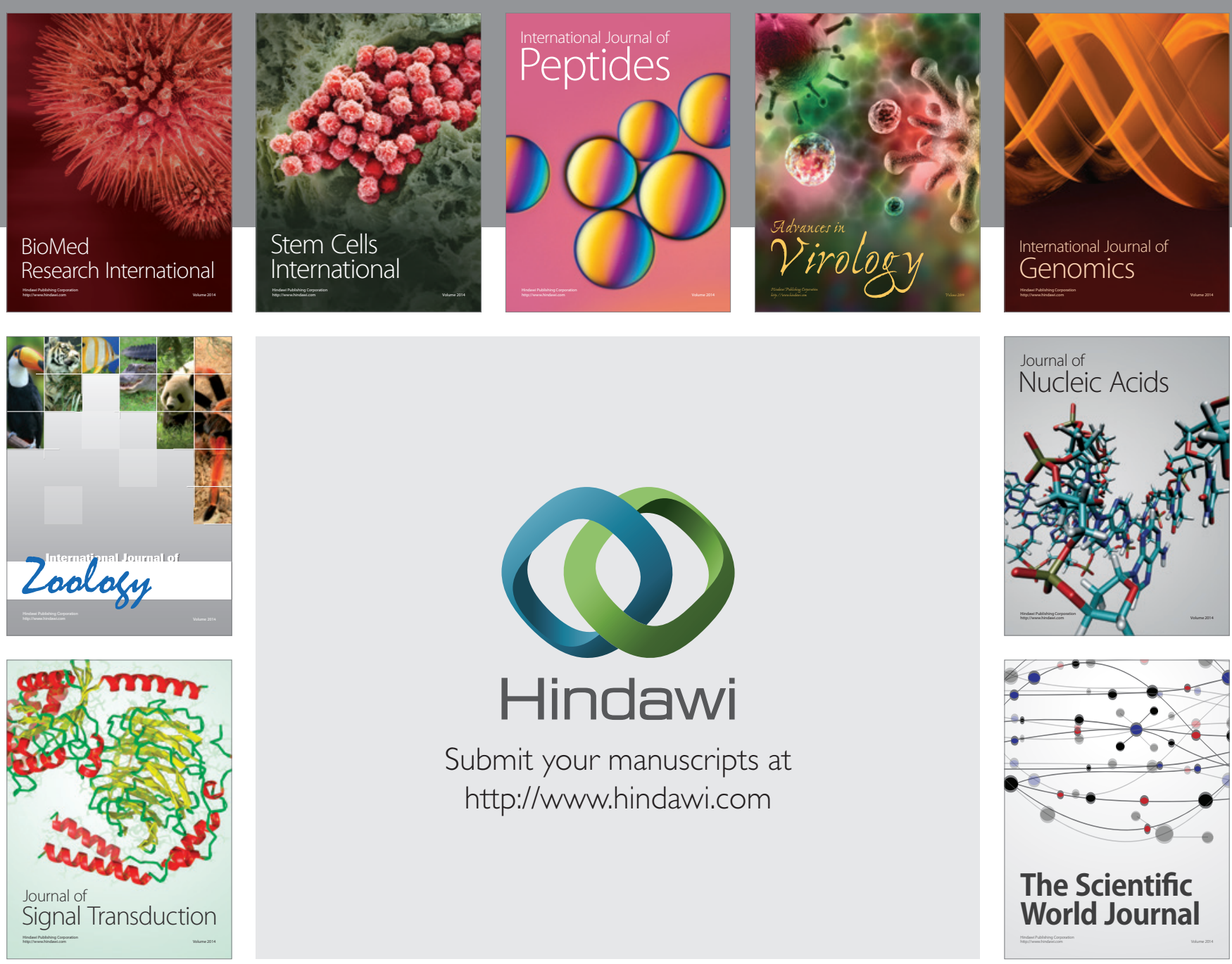

Submit your manuscripts at

http://www.hindawi.com
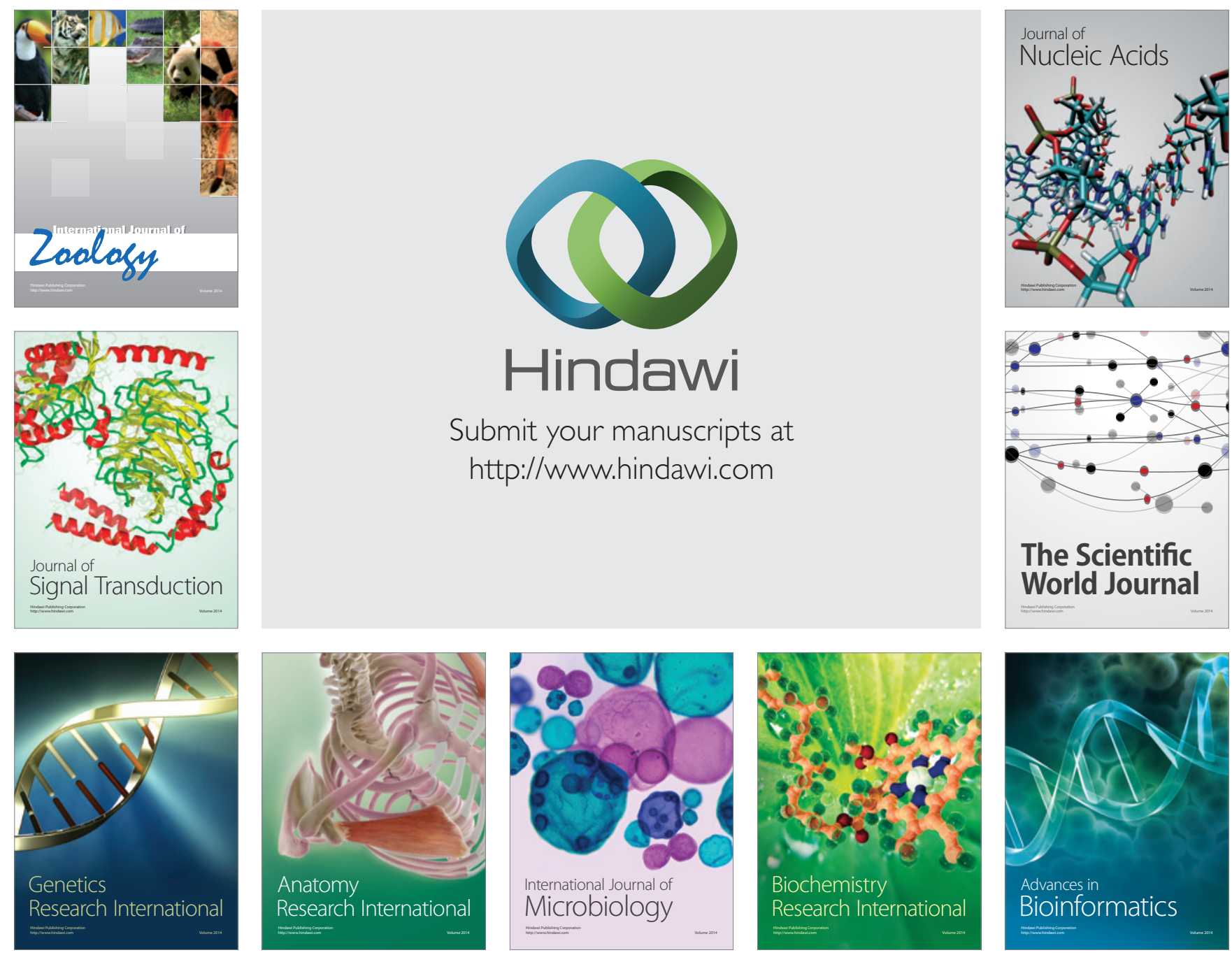

The Scientific World Journal
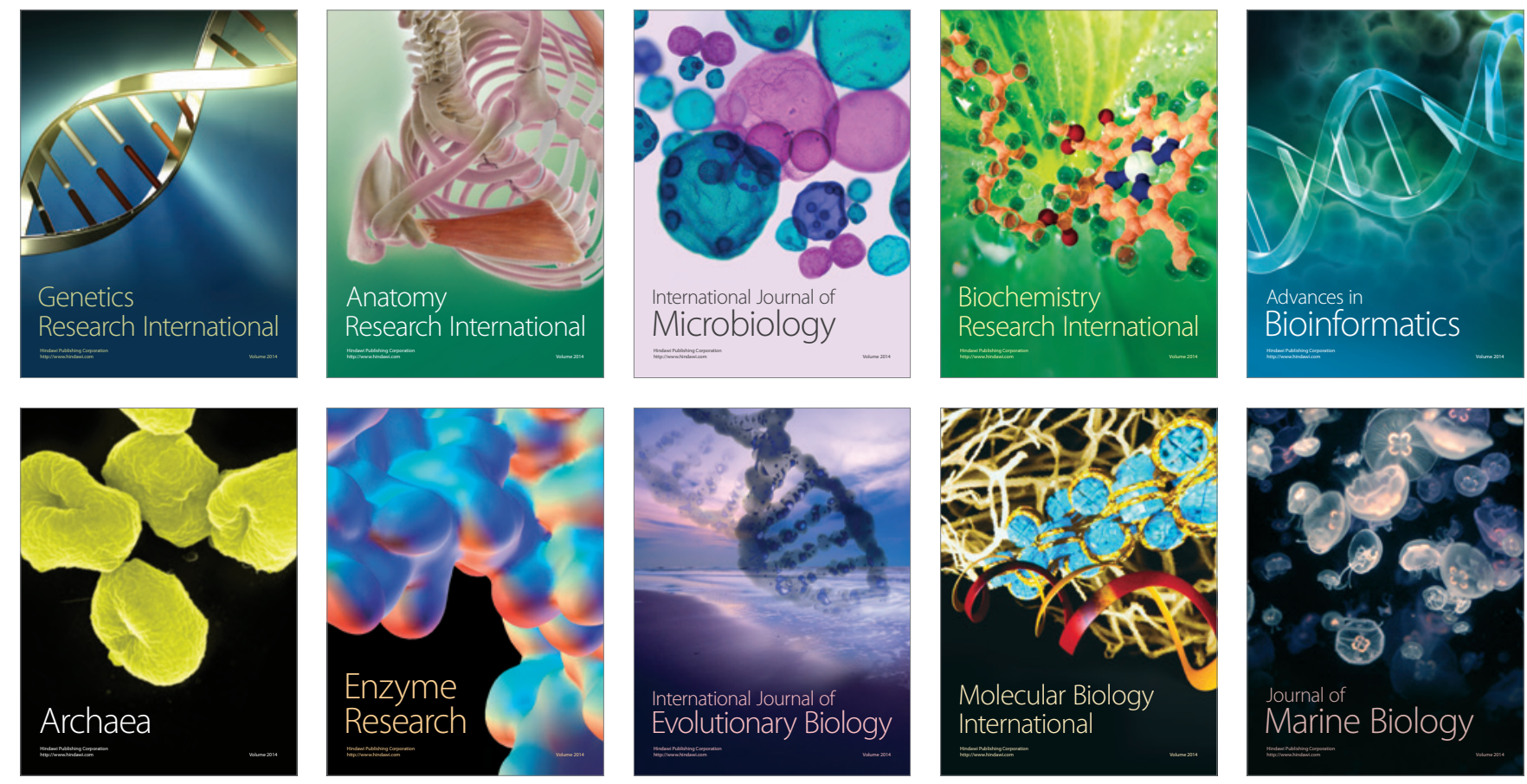